\title{
Bioaccumulation of metallic trace elements and antioxidant enzyme activities in Apfelbeckia insculpta (L. Koch, 1867) (Diplopoda: Callipodida) from the cave Hadži-Prodanova Pećina (Serbia)
}

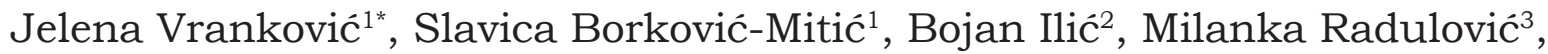 \\ Slaviša Milošević ${ }^{4}$, Slobodan Makarov ${ }^{2}$, and Bojan Mitić ${ }^{2}$ \\ ${ }^{1}$ Institute for Biological Research "Siniša Stanković", University of Belgrade, 11060 Belgrade, Serbia \\ ${ }^{2}$ University of Belgrade - Faculty of Biology, Institute of Zoology, 11000 Belgrade, Serbia \\ ${ }^{3}$ Department of Biomedical Science, State University of Novi Pazar, 36300 Novi Pazar, Serbia \\ ${ }^{4}$ Faculty of Natural Sciences and Mathematics, University of Priština, 38220 Kosovska Mitrovica, Serbia
}

Abstract: The concentration of 10 metallic trace elements or MTE (Cu, Fe, Zn, Mn, As, $\mathrm{Hg}, \mathrm{Pb}, \mathrm{Cd}$, $\mathrm{Ni}$, and $\mathrm{Cr}$ ) was measured in specimens of the troglophilic millipede Apfelbeckia insculpta (L. Koch, 1867) and sediment of the cave Hadži-Prodanova Pećina in western Serbia. Some MTE, like Fe and Mn, displayed much higher concentrations compared to other elements, both in the sediment and in the body of $A$. insculpta. On the other hand, estimation of the bioaccumulation factor (BAF) in both males and females of $A$. insculpta showed values greater than 1 for xenobiotic elements compared to those that are essential. In addition to chemical analyses, we examined the activities of antioxidant enzymes (SOD, CAT, GPX, and GR) and the phase II biotransformation enzyme GST, as well as the content of -SH groups, in the body of $A$. insculpta. Activities of two (GR and GST) out of the five tested enzymes showed significant differences between the sexes. These results represent the first comprehensive report of antioxidant enzymes in myriapods. The noted differences in the investigated MTE and enzyme activities between the sexes of $A$. insculpta most likely reflect different metabolic activities and responses to environmental conditions in males and females.

Keywords: Apfelbeckia insculpta, cave, MTE concentration, BAF, antioxidant enzyme Received 4 February 2016; Revised 23 January 2017; Accepted 23 January 2017

Citation: Vranković J., Borković-Mitić S., llić B., Radulović M., Milošević S., Makarov S. and Mitić B., 2017. Bioaccumulation of metallic trace elements and antioxidant enzyme activities in Apfelbeckia insculpta (L. Koch, 1867) (Diplopoda: Callipodida) from the cave Hadži-Prodanova Pećina (Serbia). International Journal of Speleology, 46 (1), 99-108. Tampa, FL (USA) ISSN 0392-6672 https://doi.org/10.5038/1827-806X.46.1.1981

\section{INTRODUCTION}

Trace elements, especially metallic trace elements (MTE), are considered to be one of the main pollutants in the environment since they can reside in soils for long periods and consequently have the potential to damage living organisms. Natural forms of trace elements are usually present in relatively low concentrations, but in recent years a number of anthropogenic sources, such as industrial plants, motor vehicles, thermal power stations, mines, quarries and various wasteproducing commercial enterprises, have made notable contributions to a discernible increase of environmental metal concentrations (Marjanović et al., 2009).

Due to the difficulty of accessing and studying many of their inhabitants, cave ecosystems as part of the larger karst ecosystem are one of the least known ecosystems in the world. In cave systems, the range of variation of environmental parameters, especially temperature, is narrow and light is totally absent, circumstances which exert intense evolutionary pressure on existing species (Culver \& Pipan, 2009). The cave environment depends on trophic contributions from the outside since photosynthesis is impossible in the absence of light (Paoletti et al., 2009). Food gets into a cave through natural meteorological events like floods or is brought in by trogloxenes and troglophiles who live next to the caves.

The cave Hadži-Prodanova Pećina (Figs. 1A-C) is located near a quarry on one side and next to the Ivanjica-Guča regional road near the urban settlement of Ivanjica on the other. This road passes 
about 10 feet in front of the cave entrance, making it possible for engine exhaust gases to reach inside the cave. Like every mining operation, quarrying is a destructive activity with detrimental effects on natural ecosystems. The processes involved release particulate matter and dust of different metallic constituents from the machinery and blasting and crushing of rocks (Ayodele et al., 2014), which can freely pass through the entrance of the cave HadžiProdanova Pećina and penetrate its interior, where it is deposited in the damp walls.

Certain metals [mainly those considered as "heavy metals", like mercury $(\mathrm{Hg})$, lead $(\mathrm{Pb})$, cadmium $(\mathrm{Cd})$ and arsenic (As)] are among the most abundant, toxic and persistent inorganic environmental pollutants. Metals essential for animal life include sodium, potassium, calcium, magnesium, iron $(\mathrm{Fe})$, copper $(\mathrm{Cu})$, cobalt, zinc $(\mathrm{Zn})$, nickel (Ni) and molybdenum, which are also poisonous to animals if excessive amounts are ingested (Bulog et al., 2002). Metallic trace elements present in excessive concentrations have toxic effects on organisms and can, directly or indirectly, produce reactive oxygen species (ROS), causing adverse alterations in proteins, nucleic acids and lipids, finally leading to cell death by necrosis or apoptosis (Pulido $\&$ Parrish, 2003). The excessive formation of ROS and their toxicity to the main biological components is counteracted by the activities of many antioxidant cell defence mechanisms (Stohs et al., 2000). As a part of these defence mechanisms, antioxidant enzymes include superoxide dismutase (SOD), catalase (CAT), glutathione peroxidase (GPX), glutathione reductase (GR) and the phase II biotransformation enzyme glutathione-S-transferase (GST).

Millipedes are slow-moving detritus feeders that generally spend their time burrowing through soil and litter, consuming plant remains and converting vegetable matter into humus (Brusca et al., 2016). Many species colonized caves and other subterranean habitats in which diurnal and seasonal variations in temperature and humidity are much reduced. Millipedes are often numerically dominant in these environments, which are inhabited by both surfacedwelling species that enter caves sporadically and seasonally (troglophiles) and obligate cave dwellers (troglobionts) (Culver \& Pipan, 2009). The callipodidan genus Apfelbeckia Verhoeff, 1896 is an endemic taxon which usually inhabits caves and other underground habitats of the Dinarides and Greece. Among members of the genus, Apfelbeckia insculpta (L. Koch, 1867) has the largest distributional range and can be found in Serbia, Montenegro, Bosnia and Herzegovina, Croatia and Albania (Stoev \& Enghoff, 2008; Ilić et al., 2016). In contrast to most millipedes, A. insculpta feeds on earthworms, flies, spiders, and centipedes (Hoffman \& Payne, 1969; Stoev \& Enghoff, 2008) or on decomposing animal materials (B. Ilić, pers. observ.).

Previous studies have reported on human disturbance as detrimental to the biota of caves (Bulog et al., 2002; Mikac et al., 2011), but the very limited number of them that deal with the effects of pollutants on cave organisms at the biochemical and molecular levels prompted us to undertake the present work. We here investigate the concentrations of MTE (Cu, Fe, Zn, Mn, As, Hg, Pb, Cd, Ni, and Cr) in the cave's sediment and establish their bioavailability to A. insculpta. In addition, the present study was conducted to integrate chemical analyses of selected MTE in this endemic macroinvertebrate species with its antioxidant enzyme and GST responses.

\section{MATERIALS AND METHODS}

\section{Site description and sampling}

The cave Hadži-Prodanova Pećina is situated in the valley of the river Raščićka Reka in the village of Raščići $7 \mathrm{~km}$ from the city of Ivanjica (western Serbia). The entrance to the cave lies at $630 \mathrm{~m}$ a.s.1., about $25 \mathrm{~m}$ above the valley floor. Although it is not set up for mass tourism, the cave Hadži-Prodanova Pećina is a local tourist attraction and visitors emerge as an additional factor violating the constant conditions. The

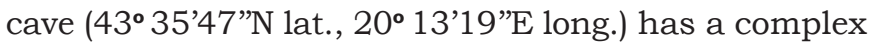
morphology with a number of lateral channels at different levels, a situation which corresponds to the type of a complex branched cave (Figs. 1A-C). Total length of the galleries is $420 \mathrm{~m}$. The gallery floor is covered with a film of water which slowly flows to the lower chambers, where it sinks or forms lakes. Generally, the explored galleries of the cave HadžiProdanova Pećina are dry, without a cave stream (Đurović, 1998).

Several cave-dwelling arthropod species inhabit this locality, among them our model organism (Fig. 1D). The population of $A$. insculpta in the cave HadžiProdanova Pećina can tolerate periodic sampling for biomonitoring because of its great abundance. It is also suitable for sampling due to easiness of collection.

In November of 2012, millipede samples were collected from the cave walls and sediment in the main passage of the cave (Fig. 1A). Samples of sediment were collected using a plastic gardening trowel and put in labeled plastic bags. We used latex gloves to reduce the possibility of contaminating the samples during collection. Between samples, the trowel was sanitized using doubly deionized water and sterile wipes. Animals were collected by hand using latex gloves and put in labeled plastic bags alive. During their collection, they were housed for a short time in boxes with sediment in order to minimize stress. Afterwards the animals were frozen in liquid nitrogen and then transported to the laboratory. Sex of the animals was determined, after which they were divided into samesize groups of males $(n=20)$ and females $(n=20)$ and subsequently stored at $-80^{\circ} \mathrm{C}$ until further analysis.

The site of sampling of sediment and animals was located in an area about 20 to $50 \mathrm{~m}$ away from the main entrance to the cave. Since the cave entrance is narrow, the sampling site was in complete darkness. Air temperature in the cave was $9^{\circ} \mathrm{C}$, while outside it was $11^{\circ} \mathrm{C}$.

\section{Sediment analysis}

Composition of the sediment was determined by element analysis. Values of moisture and element composition of the sediment are given in Table 1 . 


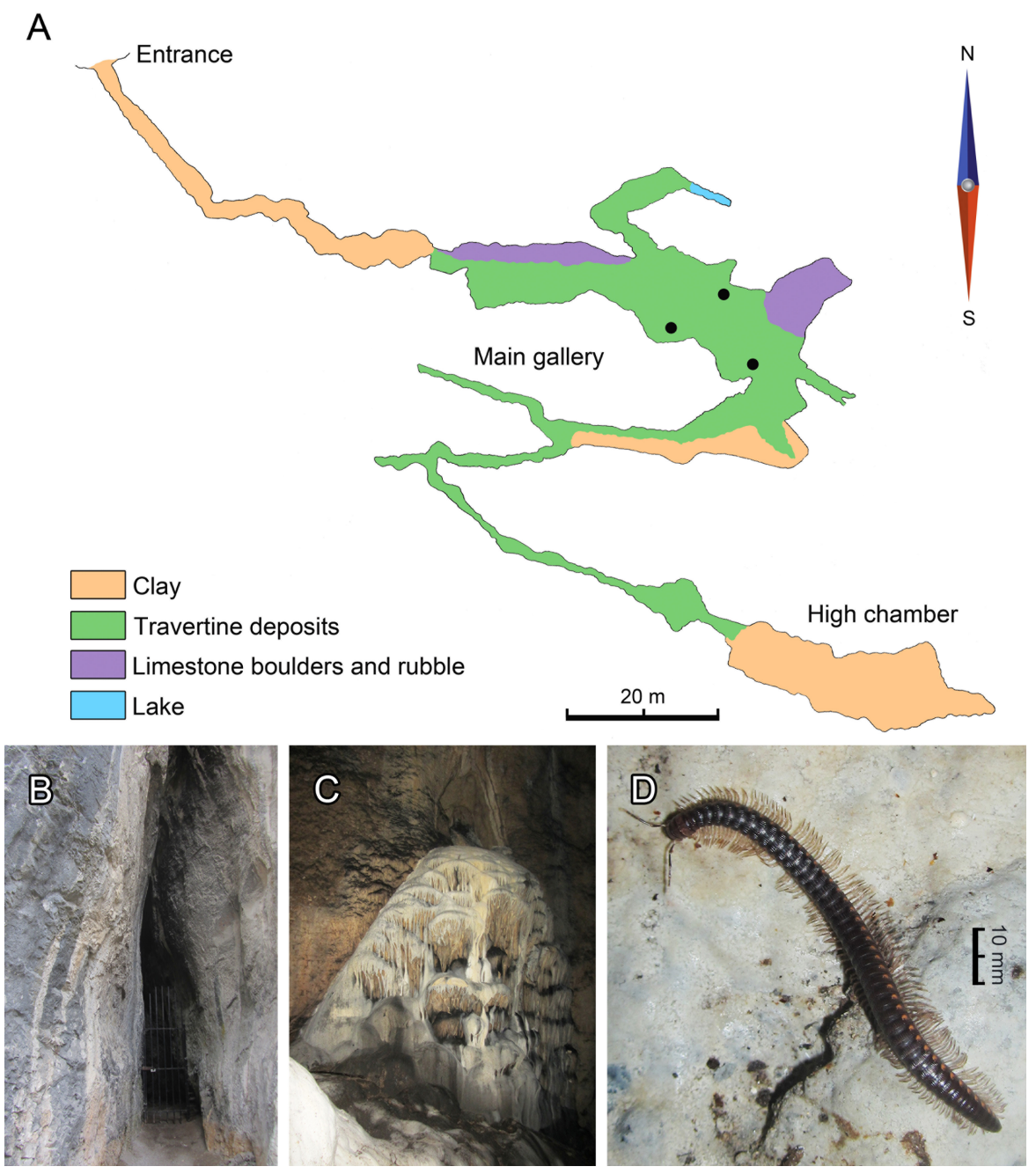

Fig. 1. A) Plan and geological settings of the cave Hadži-Prodanova Pećina (modified after Đurović, 1998), black circles represent sampling sites; B) entrance; C) details from the main gallery; D) Apfelbeckia insculpta.

Table 1. Element composition (\%) of the cave Hadži-Prodanova Pećina and N content (\%) determined by the Kjeldahl method (Bremner, 1960) in sediment and organic matter content in sediment of the cave Hadži-Prodanova Pećina with its element analysis. The percentage of moisture was obtained by subtracting the weight before and after the drying process $\left(100^{\circ} \mathrm{C}\right.$ for $\left.48 \mathrm{~h}\right)$ from a fraction of the collected sediment samples. All results are expressed in $\%$ of the dry mass.

\begin{tabular}{|c|c|c|c|c|c|c|c|c|c|c|c|c|c|}
\hline \multirow{2}{*}{ Sample } & \multirow{2}{*}{ Moisture } & \multicolumn{4}{|c|}{ Element composition (\%) } & \multirow{2}{*}{$\begin{array}{l}\text { N content (\%, by the } \\
\text { Kjeldahl method) }\end{array}$} & \multirow{2}{*}{$\begin{array}{l}\text { Organic matter (\%) } \\
\text { in the sediment }\end{array}$} & \multicolumn{6}{|c|}{ Element analysis of organic matter } \\
\hline & & $\mathrm{C}$ & $\mathrm{H}$ & $\mathrm{N}$ & $\mathrm{S}$ & & & $\% \mathrm{C}$ & $\% \mathrm{H}$ & $\% \mathrm{~N}$ & $\% \mathrm{~S}$ & $\% \mathrm{O}$ & $\mathrm{H} / \mathrm{C}$ \\
\hline Sediment & 23.78 & 46.65 & 5.22 & 3.40 & 1.23 & 2.30 & 89.25 & 56.11 & 6.22 & 3.81 & 1.38 & 36.70 & 1.34 \\
\hline
\end{tabular}

The results of element analysis of the sediment made it possible to estimate the content of organic matter and its element composition. The content of organic matter in the investigated sediment samples was determined by element microanalysis (using a Varian El III CHNS/O element analyzer from Hanau Instruments $\mathrm{GmbH}$ ) and is also shown in Table 1.

\section{Analysis of metals in sediment and animals}

Metal concentrations in the body of adult animals (20 males and 20 females) were determined after purging of their gut to ensure that the actual concentrations in their tissues are being measured. The whole animal (with aproximate body length of $89.5 \pm 0.3 \mathrm{~mm}$ and weight of $\sim 1 \mathrm{~g}$ ) was dissected (after removal of the gut) and equal $0.5-\mathrm{g}$ batches were then separated from the macerated mass for measuring of enzyme activity and the concentration of metals.

Metal content was determined in sediment and specimens of $A$. insculpta according to Beck
\& Sneddon (2000) by means of flame atomic absorption spectroscopy (using a Varian Spectra A55 spectrophotometer). To check the accuracy and precision of the instruments, the TORT- 2 certified reference material (lobster hepatopancreas reference material for trace metals from NRC Canada) was employed. The samples were oven-dried at $105^{\circ} \mathrm{C}$ to a constant weight. Digestion was performed according to a program that included warm-up to $200^{\circ} \mathrm{C}$ for $10 \mathrm{~min}$ and heating for $15 \mathrm{~min}$. After a cooling-down period, the samples were quantitatively transferred to a volumetric flask $(25 \mathrm{~mL})$ and diluted with distilled water. The metal content of samples was determined after digestion using a known analytical procedure $\left(70 \mathrm{~cm}^{3} 2 \% \mathrm{HClO}_{4}, 10 \mathrm{~cm}^{3}\right.$ conc. $\mathrm{HNO}_{3}, 5 \mathrm{~cm}^{3} 20 \%$ $\mathrm{H}_{2} \mathrm{O}_{2}$ ) (Batley, 1989). Values of ash and metal content of all samples are summarized in Table 2.

The bioaccumulation factor (BAF) was estimated for each MTE-tissue combination in order to detect the effects of elements. This was calculated as the 
Table 2. Ash content (\%) and metal trace element (MTE) content $\left(\mathrm{mg} \mathrm{kg}^{-1}\right)$ in the sediment and in the body (males and females) of Apfelbeckia insculpta collected from the cave Hadži-Prodanova Pećina. MAC(s) - maximum allowed concentrations of potentially toxic elements in the soil as prescribed by Serbian legal regulations, Official Gazette of FRY, No.23/94. MTE concentrations in 20 males and 20 females are presented as mean \pm SE. Significant differences in MTE concentrations between males and females were calculated by one-way ANOVA. The level of statistical significance of differences between the sexes was defined as $p<0.05$. Statistical significance is marked with an asterisk $\left(^{*}\right)$.

\begin{tabular}{|c|c|c|c|c|c|c|c|c|c|c|c|}
\hline & \multirow{2}{*}{$\begin{array}{c}\text { Ash } \\
\text { content (\%) }\end{array}$} & \multicolumn{10}{|c|}{ MTE concentrations $\left(\mathrm{mg} \mathrm{kg}^{-1}\right)$} \\
\hline & & $\mathbf{C u}$ & $\mathbf{F e}$ & $\mathbf{Z n}$ & Mn & As & $\mathbf{H g}$ & $\mathbf{P b}$ & $\mathbf{C d}$ & $\mathbf{N i}$ & $\mathbf{C r}$ \\
\hline Sediment & 11.20 & $\begin{array}{c}12.20 \pm \\
0.48\end{array}$ & $\begin{array}{c}10374 \pm \\
71.19\end{array}$ & $\begin{array}{l}5.91 \pm \\
3.30\end{array}$ & $\begin{array}{l}543 \pm \\
25.86\end{array}$ & $\begin{array}{l}3.92 \pm \\
1.09\end{array}$ & $\begin{array}{c}0.054 \pm \\
0.01 \\
\end{array}$ & $\begin{array}{l}1.41 \pm \\
0.13\end{array}$ & $\begin{array}{l}0.18 \pm \\
0.02\end{array}$ & $\begin{array}{l}6.73 \pm \\
1.02\end{array}$ & $\begin{array}{c}12.62 \pm \\
1.54\end{array}$ \\
\hline Males & 7.43 & $\begin{array}{c}2.32 \pm \\
0.21\end{array}$ & $\begin{array}{l}9885 \pm \\
80.31 \\
\end{array}$ & $\begin{array}{c}4.76 \pm \\
1.09 \\
\end{array}$ & $\begin{array}{r}453 \pm \\
23.65 \\
\end{array}$ & $\begin{array}{l}2.33 \pm \\
0.73\end{array}$ & $\begin{array}{c}0.057 \pm \\
0.01\end{array}$ & $\begin{array}{l}2.82 \pm \\
0.31\end{array}$ & $\begin{array}{l}0.16 \pm \\
0.05\end{array}$ & $\begin{array}{l}7.23 \pm \\
0.56\end{array}$ & $\begin{array}{c}14.25 \pm \\
1.90\end{array}$ \\
\hline Females & 6.36 & $\begin{array}{l}3.23 \pm \\
0.11^{*}\end{array}$ & $\begin{array}{l}10220 \pm \\
82.40^{*}\end{array}$ & $\begin{array}{c}3.96 \pm \\
1.26 \\
\end{array}$ & $\begin{array}{c}398 \pm \\
19.14 *\end{array}$ & $\begin{array}{l}1.48 \pm \\
0.32 \\
\end{array}$ & $\begin{array}{l}0.061 \pm \\
0.02 \\
\end{array}$ & $\begin{array}{c}2.65 \pm \\
0.23 \\
\end{array}$ & $\begin{array}{c}0.17 \pm \\
0.03 \\
\end{array}$ & $\begin{array}{l}9.31 \pm \\
0.62^{*}\end{array}$ & $\begin{array}{c}13.25 \pm \\
2.10 \\
\end{array}$ \\
\hline MAC(s) & / & 100 & / & 300 & / & 25 & 2 & 100 & 3 & 50 & 100 \\
\hline
\end{tabular}

quotient of the MTE concentration in each individual divided by MTE content in the sediment as described by Dabrowska et al. (1996).

\section{Tissue processing}

The rest of the macerated tissues (of 20 males and 20 females) was minced and homogenized in 5 volumes of $25 \mathrm{mmol} / \mathrm{L}$ sucrose containing $10 \mathrm{mmol} / 1$ Tris- $\mathrm{HCl}, \mathrm{pH} 7.5$, at $4^{\circ} \mathrm{C}$ (Lionetto et al., 2003) using an IKA-Werk Ultra-Turrax homogenizer (from Janke and Kunkel, Staufen, Germany) (Rossi et al., 1983). The homogenates were sonicated for $30 \mathrm{~s}$ at $10 \mathrm{kHz}$ on ice to release enzymes (Takada et al., 1982), and then centrifuged in a Beckman ultracentrifuge at 85,000 $\mathrm{x}$ $g$ for $90 \mathrm{~min}$ at $4{ }^{\circ} \mathrm{C}$. The resulting supernatants were used for biochemical analyses.

\section{Biochemical analyses}

The activities of antioxidant enzymes were measured simultaneously in triplicate for each sample using a Shimadzu UV-160 spectrophotometer with a temperature-controlled cuvette holder.

\section{Superoxide dismutase}

The activity of SOD was assayed by the epinephrine method (Misra \& Fridovich, 1972). One unit of SOD activity was defined as the amount of protein causing $50 \%$ inhibition of the autoxidation of adrenaline at $26^{\circ} \mathrm{C}$ and was expressed as specific activity $(\mathrm{U} / \mathrm{mg}$ protein).

\section{Catalase}

Catalase activity was evaluated from the rate of hydrogen peroxide $\left(\mathrm{H}_{2} \mathrm{O}_{2}\right)$ decomposition (Claiborne, 1984) and expressed as $\mu \mathrm{mol} \mathrm{H}_{2} \mathrm{O}_{2} / \mathrm{min} / \mathrm{mg}$ protein.

\section{Glutathione peroxidase}

The activity of GPX was determined by following the oxidation of nicotinamide adenine dinucleotide phosphate (NADPH) as a substrate with t-butyl hydroperoxide (Tamura et al., 1982) and expressed in $\mathrm{nmol} \mathrm{NADPH} / \mathrm{min} / \mathrm{mg}$ protein.

\section{Glutathione reductase}

The activity of GR was measured using the method of Glatzle et al. (1974), which is based on the ability of GR to catalyze the reduction of oxidized glutathione (GSSG) to reduced glutathione (GSH) using NADPH as a substrate in a phosphate buffer ( $\mathrm{pH}$ 7.4). Activity of this enzyme was expressed as nmol NADPH/min/ mg protein.

\section{Glutathione S-transferase}

The activity of GST towards 1-chloro-2,4dinitrobenzene (CDNB) was determined by the method of Habig et al. (1974) and expressed as nmol GSH/ $\mathrm{min} / \mathrm{mg}$ protein. The given method is based on the reaction of CDNB with the $\mathrm{SH}$ group of GSH, which is catalyzed by GST contained in the samples.

\section{-SH groups}

The concentration of sulphhydryl (-SH) groups was determined using 5,5'-dithio-bis-(2-nitrobenzoic acid) (DTNB) according to the Ellman (1959) method and expressed in $\mathrm{nmol} / \mathrm{g}$ wet mass.

\section{Protein quantification for enzymes}

Protein concentration in the supernatants was determined according to the method of Lowry et al. (1951) using bovine serum albumin as a standard.

\section{Statistical analyses}

Gender variation in MTE bioaccumulation and biochemical parameters was tested by using oneway ANOVA, followed by Tukey's post-hoc analysis. Correlation analyses were performed between biochemical data using the Pearson correlation coefficient. Differences were considered significant at $\mathrm{p}<0.05$. All analyses were performed using SAS 9.1.3 software (SAS Institute, Cary, NC, USA).

\section{RESULTS}

The quantity of mineral components of the studied sediment was expressed in the form of ash content (Table 2). Table 2 also contains data on MTE concentration in cave sediment and in A. insculpta specimens. It can be seen that the tendency of MTE presence in sediment of the cave Hadži-Prodanova Pećina was as follows: $\mathrm{Fe}>\mathrm{Mn}>\mathrm{Cr}>\mathrm{Cu}>\mathrm{Ni}>\mathrm{Zn}>$ As $>\mathrm{Pb}>\mathrm{Cd}>\mathrm{Hg}$. The level of MTE in the cave sediment was relatively high, but lower than the maximum set forth in Serbian legal regulations (Table 2). Patterns of bioaccumulation of the 10 MTE in A.insculpta differed depending on the gender. The concentrations of MTE were in the following decreasing order: $\mathrm{Fe}>\mathrm{Mn}>\mathrm{Cr}>$ $\mathrm{Ni}>\mathrm{Zn}>\underline{\mathrm{Pb}>\mathrm{Cu}=\mathrm{As}}$ (for males) and $\mathrm{Cu}>\mathrm{Pb}>$ $\underline{\text { As }}$ (for females) $>\mathrm{Cd}>\mathrm{Hg}$ (Table 2). In all specimens, 
the content of $\mathrm{Fe}$ was the highest and that of $\mathrm{Hg}$ the lowest.

In female specimens, the concentration of $\mathrm{Pb}$ was 1.88 times higher than in the sediment, while male individuals had a $\mathrm{Pb}$ concentration which was double the one in the sediment. Body concentrations of other metals were either lower than $(\mathrm{Cu}, \mathrm{Zn}, \mathrm{Mn}$, and $\mathrm{As})$ or the same as (Fe, $\mathrm{Hg}$, and $\mathrm{Cd}$ ) compared to those in the cave sediment. The concentrations of $\mathrm{Ni}$ and $\mathrm{Cr}$ in the body of the animals were slightly higher than their concentrations in the sediment (1.07 times higher in males and 1.38 times higher in females for $\mathrm{Ni}$; 1.13 times higher in males and 1.05 times higher in females for $\mathrm{Cr}$ ). In addition, measured concentrations of $\mathrm{Cu}, \mathrm{Fe}$, and $\mathrm{Ni}$ were significantly higher in female individuals compared to males, whereas the concentration of $\mathrm{Mn}$ was significantly higher in males than in females (Table 2).

Expressed as the concentration of metals in the body of $A$. insculpta divided by their concentration in the sediment, the bioaccumulation factor (BAF) can serve as an indicator of metal accumulation by the animals. In the present study, the BAF values of measured metals were estimated and compared (Table 3 ) in both genders of this callipodidan species. The tendency of BAF values determined in both genders of $A$. insculpta was as follows: $\mathrm{Pb}>\mathrm{Ni}>\mathrm{Hg}, \mathrm{Cr}>\mathrm{Fe}>\mathrm{Cd}>\mathrm{Mn}>$ $\mathrm{Zn}>\mathrm{As}>\mathrm{Cu}$.

If the BAF is lower than one $(<1)$, it indicates that accumulation in the organism is lower than that of the medium from which the xenobiotic was taken, and the organism can be considered an excluder. It can be seen from Table 3 that four of the 10 elements have the highest BAF values: $\mathrm{Pb}>\mathrm{Ni}>\mathrm{Hg}=\mathrm{Cr}$.

Table 4 shows inter-individual correlations between enzyme activities and - $\mathrm{SH}$ group concentrations in females and males. No significant association was found between CAT and GPX activity and the activities of SOD, GR and GST, or with -SH group concentrations, in female individuals according to results of the Pearson correlation test (Table 4). In females, only SOD and GR presented a significant positive relationship with GST. In addition, significant negative correlations were observed between SOD and GR activities on the one hand and - SH group concentrations on the other. In males, significant relations were few, but positive. Catalase and GPX exhibited a significant positive correlation with GST, while CAT and GPX showed a positive mutual relationship (Table 4).

Figure 2 illustrates activities of the investigated enzymes and - $\mathrm{SH}$ group concentrations in male and female individuals of A. insculpta from the cave Hadži-Prodanova Pećina. Activities of GR and GST (Figs. 2A and B) were significantly lower $(\mathrm{p}<0.05)$ in males of $A$. inculpta compared to female specimens. All other enzymes also showed lower activities in male specimens, but with a lack of statistical significance (Fig. 2). In addition, the concentration of -SH groups was lower in males compared to females without any statistically significant difference (Fig. 2C).

\section{DISCUSSION}

Mining and industrial processes lead to increased release of MTE into the surrounding environment. Accumulation of MTE is a great threat to the entire biota directly or through the food chain. Excessive amounts of various chemicals interfere with complex processes occurring in soils, modifying soil properties and assimilation of some elements by terrestrial organisms (Kania \& Lechowski, 2014).

The cave Hadži-Prodanova Pećina is located close to a granite-quarrying and stone-crushing facility, making it constantly exposed to MTE pollution. Also, this cave is home to a large population of insectivorous bats and hence has bat guano accumulations.

The most important parameters affecting MTE bioavailability are soil/sediment $\mathrm{pH}$ and organic content (Yu et al., 2001; Takáč et al., 2009). In caves, guano deposits influence sediment $\mathrm{pH}$ and organic content (Wurster et al., 2015) via the presence of phosphate and sulphate minerals characteristic of the decomposition of bat guano with the passage of time (Onac \& Forti, 2011). In addition, strongly acidic conditions are usual in guano deposits owing to the degradation of organic matter, as it is known that waste products of bacterial degradation are mostly acids (Shahack-Gross et al., 2004).

Table 3. Values of the bioaccumulation factor (BAF) for metals in males $(n=20)$ and females $(n=20)$ of Apfelbeckia insculpta collected from the cave Hadži-Prodanova Pećina (BAF values greater than 1 are presented in bold).

\begin{tabular}{|l|c|c|c|c|c|c|c|c|c|c|}
\hline \multirow{2}{*}{ Gender } & BAF & \multicolumn{10}{|c|}{$\mathrm{Pb}$} & $\mathrm{Cd}$ & $\mathrm{Ni}$ & $\mathrm{Cr}$ \\
\cline { 2 - 26 } & $\mathrm{Cu}$ & $\mathrm{Fe}$ & $\mathrm{Zn}$ & $\mathrm{Mn}$ & $\mathrm{As}$ & $\mathrm{Hg}$ & $\mathbf{1 . 0 7}$ & $\mathbf{1 . 1 3}$ \\
\hline Male & 0.19 & 0.95 & 0.80 & 0.84 & 0.59 & $\mathbf{1 . 0 6}$ & $\mathbf{2 . 0 0}$ & 0.89 & $\mathbf{1 . 3 8}$ & $\mathbf{1 . 0 5}$ \\
\hline Female & 0.26 & 0.98 & 0.67 & 0.73 & 0.38 & $\mathbf{1 . 1 3}$ & $\mathbf{1 . 8 8}$ & 0.94 & $\mathbf{1 . 3 8}$
\end{tabular}

Table 4. Overall Pearson correlations among enzyme activities and $-\mathrm{SH}$ group concentrations measured in females $(\mathrm{n}=20)$ and males $(n=20)$ of Apfelbeckia insculpta from the cave Hadži-Prodanova Pećina (statistically significant values are presented in bold).

\begin{tabular}{|c|c|c|c|c|c|c|c|c|c|c|}
\hline & \multicolumn{5}{|c|}{ Females } & \multicolumn{5}{|c|}{ Males } \\
\hline & SOD & CAT & GPX & GR & GST & SOD & CAT & GPX & GR & GST \\
\hline SOD & - & & & & & - & & & & \\
\hline CAT & 0.08 & - & & & & 0.10 & - & & & \\
\hline GPX & 0.03 & 0.19 & - & & & 0.46 & 0.64 & - & & \\
\hline GR & 0.63 & -0.24 & -0.15 & - & & -0.40 & -0.27 & -0.17 & - & \\
\hline GST & 0.64 & 0.08 & -0.15 & 0.81 & - & 0.44 & 0.68 & 0.95 & -0.27 & - \\
\hline -SH groups & -0.89 & -0.20 & 0.04 & -0.67 & -0.52 & -0.56 & -0.18 & -0.34 & 0.37 & -0.31 \\
\hline
\end{tabular}



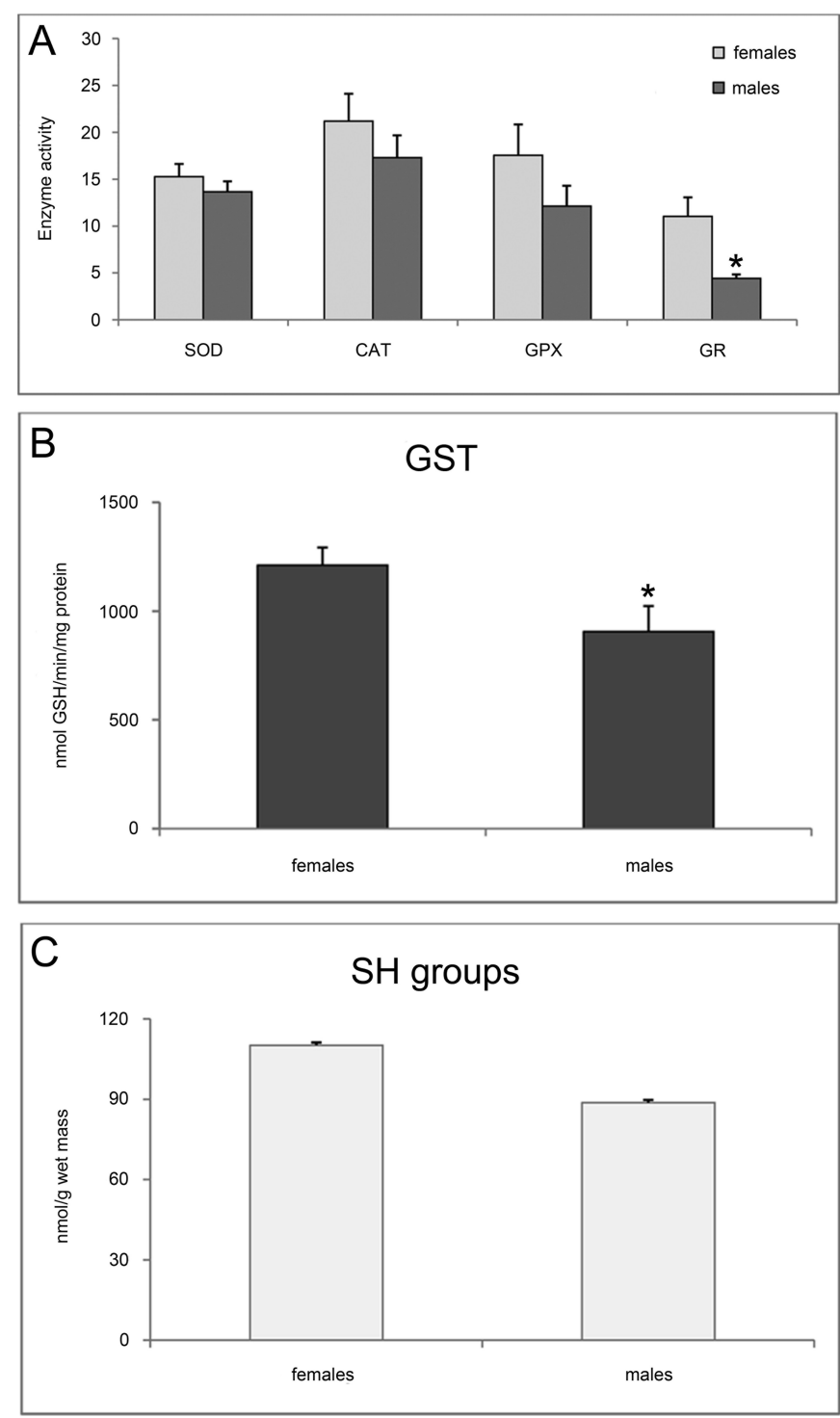

Fig. 2. A) Activities of antioxidant enzymes (SOD, CAT, GPX, and GR, expressed in respective units indicated in Materials and Methods section); B) activity of phase II biotransformation enzyme GST (nmol $\mathrm{GSH} / \mathrm{min} / \mathrm{mg}$ protein C) concentration of $-\mathrm{SH}$ groups (nmol/g wet mass) in the body of Apfelbeckia insculpta (males and females) from the cave Hadži-Prodanova Pećina. Data are expressed as means $\pm S E(n=20$ individuals per group). Statistical analysis was performed by one-way ANOVA followed by Tukey's post-hoc analysis. *Significant differences between samples. A minimum level of $p<0.05$ was accepted as significant.

Metal solubility tends to increase at lower $\mathrm{pH}$, and greater quantities of dissolved metals become potentially available for incorporation in biological processes as $\mathrm{pH}$ decreases (Salomons, 1995). In that context, our results showing BAF values for $\mathrm{Pb}, \mathrm{Ni}$, $\mathrm{Hg}$ and $\mathrm{Cr}$, greater then 1 suggest that these metals are more bioavialible than others. Apart from these elements, BAF values for $\mathrm{Fe}, \mathrm{Zn}, \mathrm{Mn}$, and $\mathrm{Cd}$ were nearly one, showing that accumulation in the organism is similar to that in the medium from which the MTE was taken. Some authors (Miko et al., 2002; Bird et al., 2007) have already suggested that cave guano is particularly enriched in transition metals (like $\mathrm{Cr}, \mathrm{Ni}$, $\mathrm{Hg}, \mathrm{Fe}, \mathrm{Cd}, \mathrm{Mn}$, and $\mathrm{Zn}$ ) compared to local soils.

The presence of high content of organic matter $(89.25 \%)$ in sediment of the cave Hadži-Prodanova Pećina could indicate increased adsorbabilities of heavy metals by the sediment and thus their lower bioaviability, as was demonstrated by Lin \& Chen
(1998), suggesting that organic substances are important scavengers of metals in river sediments.

Shahack-Gross et al. (2004) reported that sediments with higher organic content (as opposed to fresh guano) have lower $\mathrm{pH}$ values, reflecting the presence of still decomposing organic matter that is releasing acid. Keeping in mind the high organic content (Table 1) in sediment of the cave Hadži-Prodanova Pećina and the fact that lower $\mathrm{pH}$ increases bioavailability and higher organic content lowers bioavailability, we can assume the presence of still decomposing organic matter that is releasing acid. Apfelbeckia insculpta, a resident millipede species of the investigated cave, was chosen as the object of research due to its great abundance and easy availability. As the first analysis of MTE in sediment of the cave Hadži-Prodanova Pećina and the body of this European callipodidan species, our study represents a simple approach to assessment of site-specific metal bioavailability.

The elements $\mathrm{Cu}, \mathrm{Fe}, \mathrm{Zn}, \mathrm{Mn}$, and $\mathrm{Ni}$ are considered essential for living organisms. An essential metal for invertebrates which in several species can be regulated to a certain degree, $\mathrm{Cu}$ exhibits a concentration in animal bodies that is rather constant over a range of soil concentrations (Heikens et al., 2001). Copper concentrations measured in the present study were approximately four (in females) to five (in males) times lower than in the sediment (Table 2). The highest concentrations of all of the measured MTE were obtained for $\mathrm{Fe}$, but these concentrations varied in a narrow range between both genders of $A$. insculpta and the sediment.

Synergistic action of $\mathrm{Fe}$ and $\mathrm{Cu}$ when they are present in excessive concentrations may result in generation of ROS by $\mathrm{Fe} / \mathrm{Cu}$ ions via the Fenton or Haber-Weiss reactions. In addition, the $\mathrm{Cu}$ ion displays a high affinity for protein thiol and amino groups (Letelier et al., 2005). However, our results showed that regardless of the high concentration of $\mathrm{Fe}$ in the body $A$. insculpta, the BAF value for this metal is just below 1 , while the BAF value for $\mathrm{Cu}$ is very low, around 0.2 (Table 3 ). Concentrations of other essential elements $\mathrm{Zn}, \mathrm{Mn}$, and $\mathrm{Ni}$ also varied in a narrow range between males, females and the sediment, with BAF values in the range of 0.8-0.95. With respect to xenobiotic elements, As is a common constituent of most soils, whereas $\mathrm{Hg}$ and $\mathrm{Cd}$ are generally related to human activities. In spite of their low content in the sediment, $\mathrm{Hg}$ and $\mathrm{Cd}$ are toxic at much lower concentrations than the other elements analysed (US EPA 1999).

An additional mode of MTE entry into caves is via bat guano. Clark et al. (1986) reported that bats were exposed to $\mathrm{Cd}$ by ingesting insects from a polluted habitat. Cadmium-enriched guano was then voided by the bats and deposited in three caves of Florida. But to our knowledge, only a few investigations of trace metals in bat guano exist, making comparison of our results with other studies difficult. Arsenic, $\mathrm{Pb}$ and $\mathrm{Cr}$ are not essential elements and are also considered toxic. In the body of A. insculpta, the BAF value for $\mathrm{Pb}$ is above 1 in females and reaches a value of 2 in males (Table 3), suggesting a higher rate of 
accumulation than elimination of this metal in males as compared to females.

Comparing our results with those obtained in other areas affected by metal pollution, we note that concentrations of MTE (except Mn) in the cave sediment in our study are several times lower than the mean concentration in the Ebro River basin, which is heavily impacted by industrial, urban and agricultural activities (Cid et al., 2010). On the other hand, the mean values of MTE content in sediment from the cave Hadži-Prodanova Pećina obtained in the present work are very similar to those measured in soils near a granite quarry at Ikole-Ekiti in Nigeria (Ayodele et al., 2014), where assessed levels of MTE pollution indicated that some level of pollution exists, although it is low.

Soil invertebrates belonging to the same trophic level exposed to the same environmental concentrations of MTE often display different internal concentrations of elements and strategies for decontamination (Van Straalen \& Van Wensem, 1986; Grodzinska et al., 1987; Laskowski \& Maryanski, 1993). A number of them can retain metals in inactivated forms by initiating intracellular compartmentalization, which leads to bioaccumulation and some discharge of assimilated MTE into the environment. Animals which apply this strategy have the ability to concentrate elevated amounts of MTE and are considered as "macroconcentrators" (Dallinger, 1993). Employing a second strategy, "deconcentrators" are animals which possess low concentrations of MTE. On a trophic level including predators, "macroconcentrators" are represented by spiders, "deconcentrators" are represented by carabid beetles, while millipedes (the group to which $A$. insculpta belongs) are regarded as being intermediate between these two opposite strategies. It has been previously documented that diplopods themselves possess effective mechanisms to bind and detoxify MTE in tissues (Köhler et al., 1995). The first study carried out with millipedes as possible bioindicators was conducted by Hopkin et al. (1985) and involved assimilation of metals by the species Glomeris marginata (Villers, 1789). In this study with $G$. marginata, uptake of $\mathrm{Cu}, \mathrm{Zn}$ and $\mathrm{Cd}$ by animals collected in contaminated soils was shown to be higher than their uptake by animals collected in uncontaminated environments. The same authors postulated that terrestrial arthropods which feed on decomposing materials (such as some representatives of Isopoda, Collembola and Diplopoda) are among the most appropriate organisms on which to evaluate the effects of accumulation of pollutants existing in the soil, due to their direct contact with contaminants present in it.

Invertebrates, when in direct contact with MTE, may absorb them through their exoskeletons or other body coverings (Heikens et al., 2001; Hobbelen et al., 2006). Conducted by Heikens et al. (2001), studies of $\mathrm{Cd}, \mathrm{Cu}, \mathrm{Pb}$, and $\mathrm{Zn}$ accumulation in some invertebrate taxa from 1993 to 1998 showed that the content of all metals was highest in Isopoda, intermediate in Lumbricidae and low in Coleoptera. Copper and $\mathrm{Zn}$ in Diplopoda had concentrations similar to those in Isopoda, the concentration of $\mathrm{Cd}$ was high in Formicidae and Lumbricidae, whereas that of $\mathrm{Cu}$ was high in Diplopoda and Collembola. To judge from the BAF values obtained in this study, it seems more likely that certain elements accumulate to a greater extent than others. Gall et al. (2015) have suggested that due to their habitat, diets and physiological responses, certain invertebrate species may have higher accumulation rates for some MTE. Although the millipede in question feeds on animal material, it is not known to what extent its accumulated MTE concentrations originate from its prey. As for sexual differences in bioaccumulation of metals, our study showed different bioaccumulation rates for various MTE in males compared to females (Table 3). Many invertebrates (including ones that are food for $A$. insculpta) evolved metal tolerance or detoxification mechanisms like excretion of metals with their faeces, thus limiting MTE uptake and consequently reducing biomagnification onto higher trophic levels (Przybylowicz et al., 2003).

Elevated levels of MTE are associated with increased generation of reactive oxygen species (ROS) such as superoxide free radicals $\left(\mathrm{O}_{2}{ }^{-}\right)$, hydroxyl free radicals $\left(\mathrm{OH}^{*}\right)$ and non-free radical species (molecular forms) like singlet oxygen $\left(\mathrm{O}_{2}{ }^{*}\right)$ and hydrogen peroxide $\left(\mathrm{H}_{2} \mathrm{O}_{2}\right)$, which can induce oxidative stress and stimulate the involvement of antioxidant enzymes as cellular defence mechanisms for metal detoxification (Kim et al., 2014).

Superoxide dismutase represents the first line of defence in the process of ROS neutralization. This enzyme catalyzes the dismutation of superoxide anion radicals $\left(\mathrm{O}_{2}{ }^{--}\right)$to $\mathrm{H}_{2} \mathrm{O}_{2}$, which is reduced to water and molecular oxygen by CAT or through the GSH-dependent pathway. In females, concentrations of - $\mathrm{SH}$ groups displayed negative correlations with the activities of SOD and GR (Table 4). Positive correlations were obtained between GST and SOD, as well as between GST and GR, in females (Table 4). In some beetle species from metal-polluted sites, SOD activity ranged from approximately 2 to $7 \mathrm{U} \mathrm{mg}^{-1}$ protein (in our study it was around $15 \mathrm{U} \mathrm{mg}^{-1}$ protein), with values being the highest in specimens from a site with moderate to low metal pollution, while CAT showed the highest activity in beetles from sites with lower metal pollution. The CAT activity in the present work was around $20 \mu \mathrm{mol} \mathrm{H}_{2} \mathrm{O}_{2} / \mathrm{min} / \mathrm{mg}$ protein, like that measured in beetles collected from the most polluted sites (Migula et al., 2004). These values of SOD and CAT activities (Fig. 2) indicate that some factors caused increased levels of ROS in A. insculpta.

It has been previously reported that $\mathrm{Pb}$ is responsible for ROS generation (Bokara et al., 2008). Hansen et al. (2007) demonstrated that $\mathrm{Pb}$ exposure has an inhibitory effect on SOD; thus, it can cause alterations in the mitochondria and facilitate the release of $\mathrm{O}_{2}{ }^{--}$, which can inhibit CAT activity. We can assume that the presence of a higher $\mathrm{Pb}$ concentration lowers SOD and CAT activities in males compared to females (Fig. 2).

In A. insculpta, As concentration is higher in males than in females by $57 \%$, but all measured enzyme 
activities have higher values in females compared to males, indicating that the mechanism governing the arsenic-induced physiological reaction could involve decline of SOD, CAT, GPX, GR, and GST activities. Despite the fact that a statistically significant difference between genders in favour of females was obtained only for GR and GST activities (Figs. 2A and B), the validity of our findings is supported by the results of previous authors, who reported decrease of SOD (Zaman et al., 1995; Wang et al., 2006; Altikat et al., 2015), CAT (Wang et al., 2006; Altikat et al., 2015) and GPX, GR, and GST (Wang et al., 2006) activities after exposure to As.

Glutathione peroxidase in a reaction coupled with GR reduces free $\mathrm{H}_{2} \mathrm{O}_{2}$ to water and lipid hydroperoxides to lipid alcohols. Inasmuch as lower GPX activity was measured in male individuals, it would appear that metabolism of $\mathrm{H}_{2} \mathrm{O}_{2}$ and/or organic hydroperoxides is less intensive in this gender. Glutathione reductase reduces glutathione disulphide (GSSG) to the sulphhydryl form GSH, which is also an important cellular antioxidant. Glutathione-S-transferase can remove free radicals, and its levels can reflect the antioxidant capacity of the organism. Migula et al. (2004) showed that GST activity was the highest from sites with lower metal concentrations, but with values not exceeding $200 \mathrm{nmol} \mathrm{GSH} / \mathrm{min} / \mathrm{mg}$ protein, while GR and GPX exhibited a varying trend in different beetle species depending on the gradient of metal pollution. In our study, GST activity was four and six orders of magnitude (in males and females, respectively) higher than the activity mentioned above. A positive correlation between GSH-related enzymatic activities (GR, GPX, and GST activities) in both sexes of $A$. insculpta could indicate coordinated enzymatic regulation of these enzymes aimed at restoring the GSH pool, in turn permitting an efficient antioxidant response.

In view of the fact that diplopods possess effective mechanisms enabling them to bind and detoxify potentially hazardous MTE in tissues, the existence of such mechanisms in A. insculpta may explain the absence of significant differences between MTE concentration in animals and sediment.

\section{CONCLUSION}

Results of the first study of $A$. insculpta specimens from the cave Hadži-Prodanova Pećina revealed differences of MTE distribution and antioxidant enzyme activities between the sexes. The obtained BAF values showed that the rate of MTE accumulation is greater for xenobiotic elements compared to essential ones. In general, females of $A$. insculpta have higher enzyme activity and - $\mathrm{SH}$ group concentration compared to males, suggesting that the measured biochemical parameters are more inducible in female individuals. Females may be more susceptible to fluctuations in enzyme levels as a consequence of reproductive physiology or other processes operating independently from responses to the presence of MTE. In concluding this work, we emphasize the need to use local specimens to infer the effects of pollution on caves and define specific environmental quality thresholds, which will certainly contribute to the protection of this specific type of ecosystem.

\section{ACKNOWLEDGEMENTS}

This work was supported by the Serbian Ministry of Education, Science and Technological Development under Grants Nos. 173025, 173038 and 173041. We wish to thank representatives of the Tourist Organization of Ivanjica for their kindness and cooperation. Special thanks to three anonymous reviewers for their valuable comments that improved the manuscript.

\section{REFERENCES}

Altikat S., Uzsal K., Kuru H.I., Kavasoglu M., Ozturk G.N. \& Kucuk A., 2015 - The effect of arsenic on some antioxidant enzyme activities and lipid peroxidation in various tissues of mirror carp (Cyprinus carpio carpio). Environmental Science and Pollution Research, 22: 3212-3218.

https://doi.org/10.1007/s11356-014-2896-6

Ayodele O.J., Shittu O.S. \& Balogun T., 2014 - Heavy metal pollution assessment of granite quarrying operations at Ikole-Ekiti, Nigeria. International Journal of Environmental Monitoring and Analysis, 2: 333-339. https://doi.org/10.11648/j.ijema.20140206.16

Batley G.E., 1989 - Physicochemical separation method for trace metal speciation in aquatic samples. Trace Element Speciation: Analytical Methods and Problems, (Eds.), CRC Press, Boca Raton, Florida, p. 43-47.

Beck J.N. \& Sneddon J., 2000 - Use of atomic absorption spectrometry for the determination of metals in sediments and soils in Southwest Louisiana. Microchemical Journal, 66: 73-113.

https://doi.org/10.1016/S0026-265X(00)00059-X

Bird M.I., Boobyer E.M., Bryant C., Lewis H.A., Paz V. \& Stephens W.E., 2007 - A long record of environmental change from bat guano deposits in Makangit Cave, Palawan, Philippines. Earth and Environmental Science Transactions of the Royal Society of Edinburgh, 98: 59-69. https://doi.org/10.1017/S1755691007000059

Bokara K.K., Brown E., McCormick R., Yallapragada P.R., Rajanna S. \& Bettaiya R., 2008 - Lead-induced increase in antioxidant enzymes and lipid peroxidation products in developing rat brain. Biometals, 21: 9-16. https://doi.org/10.1007/s10534-007-9088-5

Bremner J.M., 1960 - Determination of nitrogen in soil by the Kjeldahl method. Journal of Agricultural Science, 55: 11-33.

https://doi.org/10.1017/S0021859600021572

Brusca R.C., Moore, W. \& Shuster, S.M., 2016 Invertebrates ( $3^{\text {rd }}$ edition). Sinauer, Cambridge, MA.

Bulog B., Mihajl K., Jeran Z. \& Toman M., 2002 Trace element concentrations in the tissues of Proteus anguinus (Amphibia, Caudata) and the surrounding environment. Water, Air and Soil Pollution, 136: 147-163. https://doi.org/10.1023/A:1015248110142

Cid N., Ibáñez C. \& Prat N., 2010 - Patterns of metal bioaccumulation in two filter-feeding macroinvertebrates: exposure distribution, inter-species differences and variability across developmental stages. Science of the Total Environment, 408: 2795-2806. https://doi.org/10.1016/j.scitotenv.2010.03.030

Claiborne A. (Eds.), 1984 - Handbook of methods for oxygen radical research, C.R.C. Press Inc., Boca Raton. 
Clark D.R. Jr., Wenner A.S. \& Morre J.F., 1986 - Metal residues in bat colonies, Jackson County, Florida, 19811983. Florida Field Naturalist 14: 38-45.

Culver D.C. \& Pipan T. (Eds.), 2009 - The biology of caves and other subterranean habitats, Oxford University Press, New York, 254 p.

Dabrowska H., Fisher S.W., Dabrowski K. \& Staubus A.E., 1996 - Dietary uptake efficiency of HCBP in channel catfish: The effect of fish contaminant body burden. Environmental Toxicology and Chemistry, 15: $746-749$.

https://doi.org/10.1002/etc. 5620150520

Dallinger R., 1993 - Strategies of metal detoxification in terrestrial invertebrates In: Dallinger R. \& Rainbow P.S., (Eds.), Ecotoxicology of Metals in Invertebrates, Lewis Publishers, 245 p.

Đurović P. (Ed.), 1998 - Speleological atlas of Serbia. Special Issues $N^{\circ} 52$. Serbian Academy of Sciences and Arts, „Jovan Cvijic“" Geographical Institute-Institute for Protection of Nature of Serbia-University of Belgrade, Faculty of Geography-Univesity of Belgrade, Faculty of Biology, 290 p.

Ellman G.L., 1959 - Tissue sulfhydryl groups. Archives of Biochemistry and Biophysics, 82: 70-77.

https://doi.org/10.1016/0003-9861(59)90090-6

Gall J.E., Boyd R.S. \& Rajakaruna N., 2015 - Transfer of heavy metals through terrestrial food webs: a review. Environmental Monitoring and Assessment, 187: 201222. https://doi.org/10.1007/s10661-015-4436-3

Glatzle D., Vuilleumier J.P., Weber F. \& Decker K., 1974 - Glutathione reductase test with whole blood a convenient procedure for the assessment of the riboflavin status in humans. Experientia, 30: 665-667. https://doi.org/10.1007/BF01921531

Grodzinska K., Godzik B., Darowska E. \& Pawlowska B., 1987 - Concentrations of heavy metals in trophic chains of Niepolomice Forest, s. Poland. Ekologia Polska, 35: 327-344.

Habig W.H., Pabst M.J. \& Jakoby W.B., 1974- Glutathione S-transferase. Journal of Biological Chemistry, 249 (22): $7130-7139$.

Hansen B.H., Romma S., Garmo O.A., Pedersen S.A., Olsvik P.A. \& Andersen R.A., 2007 - Induction and activity of oxidative stress-related proteins during waterborne $\mathrm{Cd} / \mathrm{Zn}$-exposure in brown trout (Salmo trutta). Chemosphere, 67: 2241-2249.

https://doi.org/10.1016/j.chemosphere.2006.12.048

Heikens A., Peijinenburg W.J.G.M. \& Hendriks A.J., 2001 - Bioaccumulation of heavy metals in terrestrial invertebrates. Environmental Pollution, 113: 385-393. https://doi.org/10.1016/S0269-7491(00)00179-2

Hobbelen P.H.F., Van den Brink P.J., Hobbelen J.F. \& Van Gestel C.A.M., 2006 - Effects of heavy metals on the structure and functioning of detritivore communities in a contaminated floodplain area. Soil Biology and Biochemistry, 38: 1596-1607.

https://doi.org/10.1016/j.soilbio.2005.11.010

Hoffman R.L. \& Payne J.A., 1969 - Diplopods as carnivores. Ecology, 50: 1096-1098. https://doi.org/10.2307/1936905

Hopkin S.P., Watson K., Martin M.H. \& Mould M.L., 1985 - The assimilation of heavy metals by Lithobius variegatus and Glomeris marginata (Chilopoda; Diplopoda). Contributions to Zoology, 55: 88-94.

Ilić B.S., Tomić V.T., Lučić L.R. \& Mitić B.M., 2016 Anamorphic development of Apfelbeckia insculpta ( $L$. Koch, 1867) (Diplopoda: Callipodida: Schizopetalidae). Archives of Biological Sciences, 68: 445-450. https://doi.org/10.2298/ABS150802128I
Kania G. \& Lechowski J., 2014 - Bioaccumulation of some elements in the millipede Glomeris hexasticha (Brandt, 1833) (Diplopoda, Glomerida). Journal of Elementology, 19: 155-164.

Kim B.M., Rhee J.S., Jeong C.B., Seo J.S., Park G.S., Lee Y.M. \& Lee J.S., 2014 - Heavy metals induce oxidative stress and trigger oxidative stress-mediated heat shock protein (hsp) modulation in the intertidal copepod Tigriopus japonicus. Comparative Biochemistry and Physiology - Part C, 166: 65-74.

https://doi.org/10.1016/j.cbpc.2014.07.005

Kőhler H.R., Kőrtje K.H. \& Alberti G., 1995 - Content, absorption quantities and intracellular storage sites of heavy metals in Diplopoda (Arthropoda). BioMetals, 8: $37-46$.

https://doi.org/10.1007/BF00156156

Laskowski R. \& Maryanski M., 1993 - Heavy metals in epigeic fauna: trophic-chain and physiological hypotheses. Bulletin of Environmental Contamination and Toxicology, 59: 232-240.

https://doi.org/10.1007/BF00191727

Letelier M.E., Lepe A.M., Faúdez M., Salazar J., Marín R., Aracena P. \& Speisky H., 2005 - Possible mechanisms underlying copper-induced damage in biological membranes leading to cellular toxicity. ChemicoBiological Interactions, 151: 71-82.

https://doi.org/10.1016/j.cbi.2004.12.004

Lin J.G. \& Chen S.Y., 1998 - The relationship between adsorption of heavy metals and organic matter in river sediments. Environment International, 24: 345-352. https://doi.org/10.1016/S0160-4120(98)00012-9

Lionetto M.G., Caricato R., Giordano M.E., Pascariello M.F., Marinosci L. \& Schettino T., 2003 - Integrated use of biomarkers (acetylcholinesterase and antioxidant enzymes activities) in Mytilus galloprovincialis and Mullus barbatus in an Italian coastal marine area. Marine Pollution Bulletin, 46: 324-330.

https://doi.org/10.1016/S0025-326X(02)00403-4

Lowry O.H., Rosebrough N.J., Farr A.L. \& Randall R.J., 1951 - Protein measurement with the Folin phenol reagent. Journal of Biological Chemistry, 193: 265-275.

Marjanović M.D., Vukčević M.M., Autonović D.G., Dimitriević S.I., Jovanović D.M., Matavulj M.N. \& Ristić M.D., 2009 - Heavy Metal Concentration in Soils from Parks and Green Areas in Belgrade. Journal of the Serbian Chemical Society, 74: 697-706. https://doi.org/10.2298/JSC0906697M

Migula P., Łaszczyca P., Augustyniak M., Wilczek G., Rozpędek K., Kafel A. \& Wołoszyn M., 2004 Antioxidative defence enzymes in beetles from metal pollution gradient. Biologia Bratislava, 59: 645-654.

Mikac I., Fiket Ž., Terzić S., Barešić J., Mikac N. \& Ahel M., 2011 - Chemical indicators of anthropogenic impacts in sediments of the pristine karst lakes. Chemosphere, 84: 1140-1149.

https://doi.org/10.1016/j.chemosphere.2011.04.027

Miko S., Kuhta M. \& Kepalj S., 2002 - Environmental baseline geochemistry of sediments and percolating waters in the Modric Cave, Croatia. Acta Carsologica 31: 135-149.

Misra H.P. \& Fridovich I., 1972 - The role of superoxide anion in the autooxidation of epinephrine and a sample assay for superoxide dismutase. Journal of Biological Chemistry, 247: 3170-3175.

Onac B. \& Forti P., 2011 - Minerogenetic mechanisms occurring in the cave environment: an overview. International Journal of Speleology, 40 (2): 79-98. https://doi.org/10.5038/1827-806X.40.2.1 
Paoletti M.G., Celi M., Cipolat C., Tisat L., Faccio A., Del Re A.A.M. \& Boccelli R., 2009 - Cave dwelling invertebrates: Possible bioindicators of pollution in Italian caves. Konrad Thaler Memorial Book, Contributions to Natural History, 12: 1029-1047.

Przybylowicz W.J., Mesjasz-Przybylowicz J., Migula P., Glowacka E., Nakonieczny M. \& Augustyniak M., 2003 - Functional analysis of metals distribution in organs of the beetle Chrysolina pardalina exposed to excess of nickel by Micro-PIXE. Nuclear Instruments and Methods in Physics Research B, 210: 343-348. https://doi.org/10.1016/S0168-583X(03)01029-2

Pulido M.D. \& Parrish A.R., 2003 - Metal-induced apoptosis: mechanisms. Mutation Research, 533: 227241.https://doi.org/10.1016/j.mrfmmm.2003.07.015

Regulations on Acceptable Concentrations of Hazardous and Harmful Substances in Soil and Water Used for Irrigation and on the Appropriate Research Methods, 1994 - Official Gazette RS”, no. 23/94.

Rossi M.A., Cecchini G. \& Dianzani M.U., 1983 Glutathione peroxidase, glutathione reductase and glutathione transferase in two different hepatomas and in normal liver. IRCS Medical Science: Biochemistry, 11: 805.

Salomons W., 1995 - Environmental impact of metals derived from mining activities: Processes, predictions, prevention. Journal of Geochemical Exploration, 52: 5-23. https://doi.org/10.1016/0375-6742(94)00039-E

Shahack-Gross R., Berna F., Karkanas P. \& Weiner S., 2004 - Bat guano and preservation of archaeological remains in cave sites. Journal of Archaeological Science 31: 1259-1272.

https://doi.org/10.1016/j.jas.2004.02.004

Stoev P. \& Enghoff H., 2008 - A revision of the millipede tribe Apfelbeckiini Verhoeff, 1900 (Diplopoda: Callipodida: Schizopetalidae). Steenstrupia, 29: 47-66.

Stohs S.J., Bagchi D., Hassoun E. \& Bagchi M., 2000 Oxidative mechanisms in the toxicity of chromium and cadmium ions. Journal of Environmental Pathology, Toxicology and Oncology, 19: 201-213.
Takáč P., Szabová T., Kozáková L. \& Benková M., 2009 Heavy metals and their bioavailability from soils in the long-term polluted Central Spiš region of SR. Plant Soil and Environment, 55: 167-172.

Takada Y., Noguchi T., Okabe T. \& Kayiyoma M., 1982 - Superoxide dismutase in various tissues from rabbits bearing the Vx-2 carcinoma in the maxillary sinus. Cancer Research, 42: 4233-4235.

Tamura M., Oschino N. \& Chance B., 1982 - Some characteristics of hydrogen and alkyl-hydroperoxides metabolizing systems in cardiac tissue. Journal of Biochemistry, 92: 1019-1031.

USEPA (1999) US Environmental Protection Agency: screening level ecological risk assessment protocol for hazardous waste combustion facilities. Appendix E: toxicity reference values, Table E-6, pp. 343.

Van Straalen N.M. \& Van Wensem J., 1986 - Heavy metal content of forest litter arthropods as related to body-size and trophic level. Environmental Pollution, 42: 209-221.

https://doi.org/10.1016/0143-1471(86)90032-2

Wang L., Xu Z.R., Jia X.Y., Jiang J.F. \& Han X.Y., 2006 Effects of arsenic (AsIII) on lipid peroxidation, glutathione content and antioxidant enzymes in growing pigs. Asian Australasian Journal of Animal Sciences, 19: 727-733. https://doi.org/10.5713/ajas.2006.727

Wurster C.M., Munksgaard N., Zwart C. \& Bird M., 2015 The biogeochemistry of insectivorous cave guano: a case study from insular Southeast Asia. Biogeochemistry, 124: 163-175. https://doi.org/10.1007/s10533-015-0089-0

Yu K.C., Tsai L.J., Chen S.H. \& Ho S.T., 2001-Correlation analyses on binding behavior of heavy metals with sediment matrices. Water Research, 35: 2417-2428. https://doi.org/10.1016/S0043-1354(00)00518-2

Zaman K., Macgill R.S., Johnson J.E., Ahmad S. \& Pardini R.S., 1995 - An insect model for assessing oxidative stress related to arsenic toxicity. Archives of Insect Biochemistry and Physiology, 29: 199-210. https://doi.org/10.1002/arch.940290209 